besonderem Interesse dürfte die Feststellung sein, daß von den RSV(SR)-Hamster-Tumor-Zellen, die kein infektiöses Virus mehr bilden ${ }^{3}$, ein Antigen produziert wird, welches serologische Beziehungen zu einem VirusStruktur-Antigen besitzt.

Wir danken Herrn Dr. R. J. Huebner (Bethesda, USA) für die Übersendung einer Probe des RSV(SR)-Hamster-Serums,
Herrn Dr. H. Bahnemann für die Überlassung von RSV(SR)Hamster-Serum und RSV-Antigenen, Herrn P. Giebler für die technische Durchführung der Versuche in der analytischen Ultrazentrifuge und in der $\mathrm{T}$ is elius - Elektrophorese sowie Frl. B. Lohmann für technische Assistenz. Die Untersuchungen wurden durch die Deutsche Forschungs g e m e in s ch a f $\mathrm{t}$ gefördert.

\section{Biological Activity of Phytoestrogens II}

\section{The effect of $\beta$-sitosterol on the blood picture of immature female mice}

M. I. Elghamry and M. K. Soliman

Dept. of Physiology, Faculty of Vet. Medicine, Cairo University, U.A.R.

(Z. Naturforschg. 20 b, 817-818 [1965]; eingegangen am 28. Mai 1965)

Regarding the biological activity of phytoestrogens, the literature still remains obscure and fragmentary. The relative difficulty of isolating a crystalline phytoestrogen as well as the little final yield of the compound stand as obstacles infront of detailed investigations. Recently, $\beta$-sitosterol was isolated from Glycyrrhiza glabra ${ }^{1}$ to show a higher estrogenic activity when compared with the other phytoestrogens separated from various plants, e. g. genistein ${ }^{2}$ and coumestrol ${ }^{3}$. Therefore, in studying the biological activity of this group of estrogen-like compounds, the effect of $\beta$-sitosterol upon the blood picture of immature mice is the object of this work.

\section{Materials and Methods}

Seventy-five immature female mice four weeks old were divided into 3 equal groups; the 1st of which received only cotton seed oil and kept as a control, while the $2 \mathrm{nd}$ and $3 \mathrm{rd}$ groups received $1 \mu \mathrm{g}$. and $50 \mu \mathrm{g}$. of $\beta$-sitosterol respectively. Each dose was dissolved in $0.1 \mathrm{ml}$. cotton seed oil and repeated subcutaneously for 3 days. These 2 doses were chosen particularly as the lst one is the minimum estrogenic dose while the second one represents the minimum dose that inhibits the estrogenic activity of $\beta$-sitosterol ${ }^{4}$.

Twenty-four hours after the last injection, the animals were weighed and the blood of each mouse was collected separately, after cutting the head under mild ether anaesthesia, into bottles containing ammonium

1 S. M. A. D. Z Zayed, A. Hassan, and M. I. Elghamry, Zbl. Veterinärmed. 11, 476 [1964].

2 J. D. Biggers and D. H. Curnow, Biochem. J. 58, 278 [1954].

3 R. L. Lyman, E. M. Bickoff, A. N. Booth, and A. Livingston, Biochem. and Biophysics 80, 61 [1959].

4 A. Hassan, M. I. Elghamry, and S. M. A. D. Zayed, Naturwissenschaften 17, 409 [1964].

5 V. G. Heller and H. Paul, J. Lab. clin. Med. 19, 777 [1934].

6 L. Halmann, Klinische Chemie und Mikroskopie 6. Aufl. G. Thieme-Verlag, Leipzig 1955. and potassium oxalate ${ }^{5}$ as anticoagulant. Then, the mice were opened and the uteri were dissected carefully and weighed to be used as a criterion for estrogenic activity.

Hayem's and Turk's solutions were used for dilution of the erythrocytes and leucocytes respectively. The blood corpuscles were counted in an improved double neubaver chamber. From each animal, two blood films were stained with the panoptic method of Papenherm ${ }^{6}$ and 400 cells were differentiated after the four field meander method ${ }^{7}$. S a h li's hemometer was used for determining the hemoglobin content and the sedimentation rate was carried out by LANDAU microsedimentation method ${ }^{8}$. The packed cell volume was measured by the microhematocrit tubes ${ }^{9}$. Then, all the data were analysed statistically using the " $t$ " test.

\section{Results and Discussion}

Application of small and large doses of $\beta$-sitosterol exerted a significant influence on the corpuscles and certain properties of blood in immature female mice (table 1). Although $50 \mu \mathrm{g}$. of the phytoestrogen did not show a significant increase in the uterine weight, which is due to the inhibiting action of large doses of this estrogen-like compound ${ }^{4}$, yet its influence on the blood picture is quite clear. Both $1 \mu \mathrm{g}$. and $50 \mu \mathrm{g}$. of $\beta$-sitosterol reduced the hemoglobin content of the blood, a finding which can be attributed to the decreased erythrocyte count.

As a result of the great increase in neutrophils and the less pronounced decrease in lymphocytes and eosinophils a high total count of leucocytes was generally observed. This effect of $\beta$-sitosterol simulates the action of animal and synthetic estrogens. Neutrophelia appeared in rats, rabbits, dogs and human ${ }^{10}$ and in the horse and cat ${ }^{11}$ after administration of estrogens. The same treatment produced lymphopenia in man and experimental animals ${ }^{12,13}$, an effect which Selye and MARION $^{14}$ attributed to the depressive action on the

7 O. W. Schalm, Veterinary Hematology. 1st Ed., Bailliere, Tindall \& Cox, London 1961.

8 A. Landau, Amer. J. Diseases Children 45, 692 [1933].

9 R. A. McInroy, J. clin. Pathol. 7, 32 [1954].

10 O. Feuchtinger, Z. klin. Med. 141, 697 [1942].

11 H. Tillman and W. Gehring, Zbl. Veterinärmed. 1, 49 [1953].

12 S. R. Diesterbeck, Zbl. Gynäkol. 71, 412 [1949].

13 P. Larriza, A. Notario, and S. Ventura, Acta Hematologia 33, 391 [1949].

14 H. Selye and D. Marion, Acta Anatom. 23, 180 [1955]. 
lymphatic system. Also, eosinopenia appeared in the cat ${ }^{11}$ following estrogen administration, while Bottlglioni and Sturani ${ }^{15}$ found that treatment with estrogens resulted in eosinophelia in man as well as in cattle ${ }^{16}$.

This action of estrogens upon the leucocytes has been explained by: a) a direct action on the haemopoietic organs either by stimulating the maturation of the cells in the bone marrow with a consequent release of leucocytes or by increasing the rate of release of mature leucocytes already in reserve ${ }^{17}$; b) an indirect action via the neurohormonal control of leucopoiesis particularly ACTH ${ }^{18}$.

The whole series of this work will stimulate the discussion of the economic use of phytoestrogens in therapy instead of the known animal and synthetic estrogens. This point waits the discovery of a phytoestrogen which is enough potent biologically.

15 E. Bottlglioni and R. L. Sturani, Arch. E. Moragl. Pathologia [Genova] 4, 1149 [1949].

16 B. Gaudlitz, Inaug. Diss., Berlin 1955.

17 R. Moberg, Thesis, Stockholm 1955.

18 Th. Dougherty and J. A. Frank, J. Lab. clin. Med. 42, 530 [1953].

\begin{tabular}{|c|c|c|c|}
\hline \multirow{2}{*}{ Indicator } & \multirow{2}{*}{ Control } & \multicolumn{2}{|c|}{$\beta$-sitosterol } \\
\hline & & $1 \mu \mathrm{g}$. & $50 \mu \mathrm{g}$. \\
\hline $\begin{array}{l}\text { Av. body weight } \\
\text { (gm.) }\end{array}$ & $9.80 \pm 0.22$ & $10.38 \pm 0.33 *$ & $9.37 \pm 0.41^{*}$ \\
\hline $\begin{array}{l}\text { Av. Uterine wt. } \\
\text { (mg.\%) }\end{array}$ & $54.50 \pm 2.11$ & $68.24 \pm 3.28$ & $58.61 \pm 2.49 *$ \\
\hline $\begin{array}{l}\text { R.B.Cs. (mil./ } \\
\text { cu. mm.) }\end{array}$ & $5.51 \pm 0.19$ & $4.61 \pm 0.18$ & $3.49 \pm 0.23$ \\
\hline ml.) & $12.03 \pm 0.57$ & $10.19 \pm 0.12$ & $10.56 \pm 0.18$ \\
\hline PCV (mm.) & $36.11 \pm 0.37$ & $30.65 \pm 0.49$ & $31.76 \pm 0.49$ \\
\hline $\begin{array}{l}\text { Sed. rate }(\mathrm{mm} . / \\
3 \text { hours) }\end{array}$ & $0.84 \pm 0.16$ & $1.11 \pm 0.08 *$ & $0.70 \pm 0.13 *$ \\
\hline $\begin{array}{l}\text { W.B.Cs.(thous.) } \\
\text { cu. mm.) }\end{array}$ & $13.03 \pm 0.48$ & $17.22 \pm 0.47$ & $18.65+0.63$ \\
\hline $\operatorname{Stab}[\%]$ & $0.53 \pm 0.09$ & $2.15 \pm 0.30$ & $3.16 \pm 0.26$ \\
\hline Neutrophils [\%] & $15.42 \pm 0.64$ & $39.88+1.92$ & $42.12+183$ \\
\hline Eosinophils [\%] & $2.00 \pm 0.20$ & $0.65 \pm 0.15$ & $1.00 \pm 0.22$ \\
\hline Basophils [\%] & $0.23 \pm 0.09$ & $0.06 \pm 0.04 *$ & - \\
\hline $\begin{array}{l}\text { Lymphocytes } \\
{[\%]}\end{array}$ & $79.70 \pm 0.78$ & $58.34 \pm 2.06$ & $50.52 \pm 1.91$ \\
\hline Monocytes [\%] & $2.12 \pm 0.17$ & $2.98 \pm 0.37$ & $3.20 \pm 0.21$ \\
\hline
\end{tabular}

Table 1. Blood changes in female mice after administration of $1 \mu \mathrm{g}$. and $50 \mu \mathrm{g}$. of $\beta$-sitosterol. $\pm=$ Standard error. * = The difference between control and experimental mice was insignificant. This difference in all the other data is statistically significant.

\section{Photoperiodische Steuerung der 15-tägigen lunaren Metamorphose-Periodik von Clunio-Populationen (Diptera: Chironomidae)}

\section{Dietrich NeumanN \\ Zoologisches Institut der Universität Würzburg \\ (Z. Naturforschg. 20 b, 818-819 [1965]; eingegangen am 17. Mai 1965)}

Die an gezeitenstarken Meeresküsten lebenden Populationen der Mücke Clunio marinus zeigen eine annähernd 15-tägige Schlüpf- und FortpflanzungsPeriodik ihrer Imagines ${ }^{1-3}$. Die Schlüpfphasen sind auf bestimmte Niedrigwasserzeiten des 14,8-tägigen, zwischen Spring- und Nipptiden wechselnden Gezeitenzyklus abgestimmt und laufen damit parallel zum 29,5tägigen Mondphasenzyklus. An der Normandieküste (Frankreich) beginnen sie an den Voll- und Neumondterminen und erstrecken sich jeweils über 4-5 Tage, an denen die nur wenige Stdn. lebenden Imagines um die Zeit des Nachmittags-Niedrigwassers erscheinen.

Wenn Clunio-Kulturen im künstlichen Tag-NachtWechsel gehalten werden, so tritt keine periodische Schlüpfverteilung auf (Abb. 1 a, Summendiagramm von 5 Kulturen); die Entwicklungsdauer schwankt zwischen 45 und etwa 100 Tagen. Wenn die Kulturen zusätzlich einem künstlichen Mondlicht ausgesetzt werden, und zwar in einem 30-tägigen Belichtungszyklus (entsprechend der Dauer eines synodischen Monats),

1 R. Chevrel, Arch. Zool. exp. gen. Ser. 3, 2, 583 [1894].

2 H. Caspers, Arch. Hydrobiol., Suppl. Bd. 18, 415 [1951]. so stellt sich eine auffällige 15-tägige Schlüpfperiodik ein (Abb. 1 b, Summendiagramm von 4 Kulturen, Schlüpfmaxima bei $63,1,78,3$ und 92,8 Tagen). Die Schlüpfphasen lassen sich durch eine Verschiebung des künstlichen Mondlichtzyklus auch auf andere Tage verlegen, sie fallen jedoch stets auf die Tage mit Dämmerlichtnacht und auf die zwei Wochen später liegengen Tage. Diese im Laboratorium ausgelöste Periodik entspricht der Schlüpfperiodik der Freilandpopulationen. Vermutlich können daher auch im Freiland die Schlüpfphasen unabhängig von den Gezeitenbedingungen allein durch den periodischen Wechsel von mondhellen und dunklen Nächten gesteuert werden.

Die Metamorphosestadien treten jeweils erst kurz vor den Schlüpftagen auf (Puppendauer + : $2-3$, ô: $3-5$ Tage bei $20^{\circ} \mathrm{C}$ ). Die 15-tägige Schlüpfperiodik beruht daher auf einer MetamorphosePeriodik der Populationen. Erhält eine Larvenpopulation im IV. Larvenstadium nur eine einmalige Dämmerlichtbehandlung, aus der sie weder einen Hinweis auf eine 30-tägige noch eine 15-tägige Periodendauer entnehmen kann, so stellt sich gleichfalls eine annähernd zweiwöchige Periodik ein (Abb. l c, Summendiagramm von 6 Kulturen aus 3 Versuchsserien, Schlüpfmaxima bei $62,0,76,2$ und 89,0 Tagen). Die Metamorphose-Periodik der Larvenpopulationen muß daher auf einer endogenen, und zwar angeborenen Periodik beruhen, die mit gleicher Periodendauer in

3 Н. Ока и. Н. НаSнiмото, Biol. Zbl. 78, 545 [1959]. 